\title{
THE IMPACT OF MONETARY POLICY DECISIONS ON STOCK PRICES: AN EVENT STUDY
}

\author{
DOI: 10.17261/Pressacademia.2021.1422 \\ PAP- V.13-2021(11)-p.52-56
}

\section{Sule Baykara}

Kadir Has University, Banking and Finance, Istanbul, Turkey.

sule.baykara@stu.khas.edu.tr, ORCID: 0000-0002-7987-2906

To cite this document

Baykara, S., (2021). The impact of monetary policy decisions on stock prices: an event study. PressAcademia Procedia (PAP), V.13, 52-56.

Permanent link to this document: $h$ ttp://doi.org/10.17261/Pressacademia.2021.1422

Copyright: Published by PressAcademia and limited licensed re-use rights only.

\begin{abstract}
Purpose- Stock market is one of the markets where the effects of monetary policy decisions, which is determined by central banks, are felt quickly. Changes in interest rates enable monetary policy decisions to be transferred to the economy by affecting the stock prices. The purpose of this study is to examine the effect of policy interest rate announcements of Central Bank of Republic of Turkey (CBRT) on stock prices of specific sectors in Istanbul Stock Exchange (ISE) Market.

Methodology- Brown and Warner (1985) event study methodology is used to examine the stock price response of banking and insurance firms traded in ISE. Sample consist of 18 firms which 12 are banks and 6 are insurance firms between January 1, 2015 and December 31, 2020. Monetary policy meeting announcements are taken as the event which are only related to the up movements of policy interest rate. Abnormal returns (AR) and cumulative average abnormal returns (CAAR) are calculated and t-test is applied within the scope of the study. Findings- Through the sample period there are only three announcements including increase in policy interest rates. Findings show that there is negative price response in banking and insurance firms when the monetary policy interest rates go up.

Conclusion- In this study, the effect of the monetary policy interest rate announcements made by the Central Bank of Republic of Turkey (CBRT) between the years 2015-2020 on the returns of banks and insurance companies was examined by using the event study methodology. According to results of the analysis, it has been determined that the CBRT's decision to raise interest rates has a significant negative effect on banks and insurance firms which are traded in Istanbul Stock Exchange (ISE) market. These findings show that monetary policy announcements in Turkey affects financial markets through the policy rate channel and there is a strong transmission mechanism between them.
\end{abstract}

Keywords: Monetary policy decisions, stock prices, event study, Brown and Warner, ISE. JEL Codes: G10, G12, G14

\section{INTRODUCTION}

Monetary policy aimed to ensure macroeconomic targets which are basicaly price stability and economic growth. Central banks are responsible institution that use monetary policy tools to achieve the determined final targets. The global crisis revealed that the increase/decrease in the prices of financial assets and the resulting risk should not be ignored while the central banks focus on price stability. Particularly, the global crises experienced, monetary policy decisions implemented by central banks in developing countries may adversely affect stock prices and this may cause a decrease in the demand for capital markets. An increase/decrease in interest rates in line with monetary policy shocks may affect the expectations of market participants and may cause stock prices to decrease due to their willingness to invest in different financial assets.

An increase in the money supply may cause inflation, which may adversely affect the capital markets. Also, an increase in the exchange rate in the face of monetary policy shocks may have a negative effect on stock returns, causing the markets to react negatively. Empirical studies show that contractionary monetary policy shocks can have a negative effect on stock prices in the short run. However, markets with high volatility in stock prices react more strongly to monetary policy decisions. The reason for this is thought to be due to the immediate and direct reaction of the markets due to the strong relationship between monetary shocks and the stock market. In the literature, it is possible to find many studies examining the relationship between monetary policy decisions and stock prices.

The purpose of this study is to examine the impact of monetary policy decisions on banking and insurance sector in Istanbul Stock Exchange market with Brown and Warner (1985) event study methodology. Study differs itself from previous studies by focusing only banking and insurance stocks traded in ISE. The paper is organized as follows: Part two presents literature review of the event studies on the subject; part three provides the methodology of the study; finally, results and conclusion take place in part four and five. 


\section{LITERATURE REVIEW}

Monetary policy can be defined as the use of monetary tools by central banks to achieve the ultimate goals such as ensuring economic growth, price stability and employment. Within the framework of the monetary transmission mechanism, one of the channels of monetary policy affecting the economy is the stock market. Stock prices are among the asset prices that can be observed in the economy and are immediately and directly affected by monetary decisions. So, information dissemination between the monetary policy announcements and stock prices is the subject of Efficient Market Hypothesis (EMH). According to the $\mathrm{EMH}$, the prices of securities traded in the market contain all the information, news and expectations of the securities they are related to (Fama, 1970). According to the Fama (1970), there is a relationship between security prices and information, and security prices are always formed according to new information announced. Therefore, monetary policy announcements should have an effect on stock prices.

Many studies have been conducted to examine the impact of monetary policy decisions on the stock market. Cook and Hahn (1989) examined the effects of the changes in the federal funds rates of the FED between 1974 and 1979 on the stock prices. The total number of days in which interest changes occurred between these years was determined as 75 days in the study. Results showed that the relationship between the two variables was negative. This means that when the policy interest rate is increased (decreased) by the central bank, the prices of stocks traded in the stock market decreases (increases).

Edelberg and Marshall (1996) conducted a study that examines the impact of the Fed's interest policy on the stock market more deeply in an econometric perspective with the daily effects of monetary policy. In this study, the Structural Vector Auroregression (SVAR) method is used, the unexpected effects of monetary policy are especially focused. The expectation model created by the authors was then integrated into the stock response function and the effects of expectations regarding monetary policy were examined. They showed that unexpected monetary policy shocks create greater effects on stock prices than expected shocks.

Fair (2006) examined the effect of monetary policy on stock prices in the USA. The findings are obtained from the study show that the rapid and sudden price changes in the stock market are affected by monetary policy decisions.

Conover et al. (1999), investigated the degree to which stock markets are affected by US and national monetary policies in Austria, Belgium, Canada, Finland, Germany, France, Ireland, Italy, Japan, Netherlands, New Zealand, South Africa, Sweden, Switzerland, United Kingdom, and USA between January 1956 and December 1995. According to the results, they concluded that both the US central bank and the national central banks reacted positively in the periods when the monetary expansion decision was made, and the returns were generally higher during these periods.

Rigobon and Sack (2004) analyzed the effect of monetary policy on the stock market in the US between 1994-2001 by event study method. They concluded that stock returns react negatively to changes in interest rates that occur in monetary policy decisions.

In the study conducted by Andersson (2007), daily data were used, and the effect of the Fed's interest rate decisions on the returns of stocks in the Euro Zone and the effects of the ECB's interest rate decisions on the returns of American stocks were also examined. The findings obtained showed that the American interest rate decisions affect the returns of stocks in both America and Europe, but the ECB's decisions do not affect the returns of stocks in the United States.

D'Amico and Farka (2002) examined the impact of monetary policy decisions when they were announced. They use the prices of the securities traded in the markets 5 minutes before and five minutes after monetary policy decision is announced. In order to proxy this, structural VAR and IV method are developed. The difference between these two prices has been defined as a policy shock. Then, they analyzed the change in stock returns of this shock. Findings from the study show that monetary policy decisions closely affect stock prices within the first five minutes.

In the study conducted by Duran et al. (2010), the results show that an increase in policy rates reduce stock prices at varying rates depending on the sectors. Especially the reason why the financial sector index is affected more by policy rates compared to other sectors is that firms included in this index are more sensitive to interest than other firms.

In another study, Vinod et al. (2020) found that when monetary policy decisions are announced the 13 Indian firms in the stock market response inversely. They use event study methodology to show the abnormal returns between March 11, 2016 to August 30,2019 within [$15,+15$ ] event period.

Gökalp (2017) uses OLS method to estimate the impact of expected and unexpected monetary decisions on BIST100 index, service sector index, financial sector index, industrial sector index, and technology index between Jan 2005 - Dec 2015. Sample contains 132 interest decision periods. He found that unexpected increase in policy interest by $1 \%$, stock prices decrease by $5.6 \%$ and expected changes are observed insignificant in the model.

If the studies are gathered in the literature in terms of their common results, Bernanke and Kuttner (2005), He (2006), Jensen et al. (1996), and Thorbecke (1997) showed that monetary policy announcements and stock prices are negatively related.

According to the previous literature presented above, negative price response is expected against to the up movements of monetary policy interest rate and hypothesis are listed as follows:

$\mathrm{HO}$ : There will be no stock price response to increase in monetary policy interest rate announcements of CBRT.

$\mathrm{H1}$ : The will be negative stock price response to increase in monetary policy interest rate announcements of CBRT. 


\section{DATA AND METHODOLOGY}

Sample is formed by using the Bloomberg HP (historical price) function for two different sectors; banking (XBANK) and insurance (XSGRT) firms which are traded in the ISE and the monetary policy decision meeting announcements are gathered from the CBRT website between January 2015 - December 2020. Announcements contain the up, down, and no changes in the monetary policy interest rate. Only the first up movements of the rates are examined, and others are excluded. So, there are three announcements in five years. Table 2 shows the firms in the sample.

Table 2: Summary of the Sample Based on Sectors and Firms

\begin{tabular}{|c|c|c|}
\hline Sectors & Equity Name & Firm Name \\
\hline & $\begin{array}{l}\text { AKBNK TI Equity } \\
\text { ALBRK TI Equity } \\
\text { ICBCT TI Equity } \\
\text { QNBFB TI Equity } \\
\text { SKBNK TI Equity } \\
\text { GARAN TI Equity } \\
\text { HALKB TI Equity } \\
\text { ISCTR TI Equity } \\
\text { KLNMA TI Equity } \\
\text { TSKB TI Equity } \\
\text { VAKBN TI Equity } \\
\text { YKBNK TI Equity }\end{array}$ & $\begin{array}{l}\text { Akbank } \\
\text { Albaraka Türk Katılım Bankası } \\
\text { ICBC Turkey } \\
\text { QNB Finans Bank } \\
\text { Sekerbank } \\
\text { Garanti Bankası } \\
\text { Halk Bank } \\
\text { Is Bank } \\
\text { Türkiye Kalkınma Bankası } \\
\text { Türkiye Sanayi ve Kalkınma Bankası } \\
\text { Vakıf Bank } \\
\text { Yapı Kredi Bankası }\end{array}$ \\
\hline 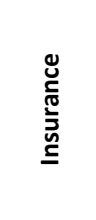 & $\begin{array}{l}\text { AKGRT TI Equity } \\
\text { ANSGR TI Equity } \\
\text { ANHYT TI Equity } \\
\text { AVISA TI Equity } \\
\text { RAYSG TI Equity } \\
\text { TURSG TI Equity }\end{array}$ & $\begin{array}{l}\text { Aksigorta AS } \\
\text { Anadolu Anonim Turk Sigorta Sirketi } \\
\text { Anadolu Hayat Emeklilik AS } \\
\text { AvivaSA Emeklilik ve Hayat AS } \\
\text { Ray Sigorta AS } \\
\text { Türkiye Sigorta AS }\end{array}$ \\
\hline
\end{tabular}

In the study, Brown and Warner (1985) event study methodology is followed. The main objective of an event study is to quantify the abnormal returns in the stock market based on political or economic events. Basically, study is interested in the relationship between stock price responses and monetary policy announcement on monetary policy interest rate. 250 daily stock returns are used, and estimation period is designed as $[-244,-6]$ for each security. $[-5,+5]$ is designed as event period. For each stock in the sample, trading must be at least 30 days in the 250 day period and no missing return in the last 20 days. (See Figure 1 )

\section{Figure 1: Estimation Window and Event Window}

Event Date (0)

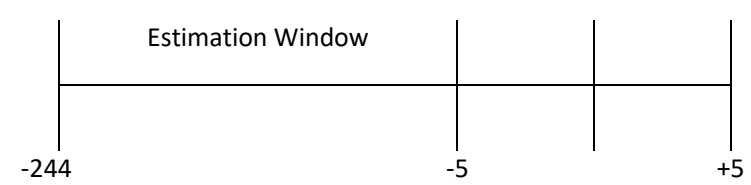

Event Window

The abnormal returns are calculated as; $A_{i, t}=R_{i, t}-R_{m, t^{\prime}}$

Where Ri,t is the arithmetic return for security $i$ at day $t . R m, t$ is the equally weighted index of XBANK and XSGRT for day $t$. Ai,t is defined as the excess return for security $i$ at day $t$. The statistical significance of the average abnormal return of event period is measured by using $t-$ statistics.

$$
\bar{A}_{t} / \hat{S}\left(\bar{A}_{t}\right)
$$

where,

$$
\begin{gathered}
\hat{S}\left(\bar{A}_{t}\right)=\sqrt{\left(\sum_{t}^{t=-244} \overline{\mathrm{A}} t-A\right)^{2} / 238,}, \\
\mathrm{~A}=\frac{1}{239} \sum_{-244}^{-6} \overline{\mathrm{A}} t
\end{gathered}
$$


The cumulative abnormal returns (CAAR) are calculated by the summation of average abnormal returns on each day of the event period.

$$
\operatorname{CAAR}(-5,+5)=\sum_{-5}^{5} \bar{A} t
$$

\section{FINDINGS}

Table 3 presents the cumulative and average abnormal returns with their t-statistics. As it is expected, cumulative abnormal returns are negative around the announcement of increase in monetary policy interest rate and t-tests are negative and significant. The results are compatible with the studies with the previous literature.

So, $\mathrm{H} 1$ hypothesis is accepted which shows that there is negative relationship between rising interest rates and stock returns of banking and insurance firms. Turkish banking and insurance sectors gives negatively price response to the announcement of monetary policy related to monetary policy interest rate.

\begin{tabular}{|c|c|c|c|c|c|}
\hline \multirow{2}{*}{$\begin{array}{c}\text { Event } \\
\text { Window }\end{array}$} & \multirow[t]{2}{*}{ Event Date } & \multicolumn{2}{|c|}{ Banking } & \multicolumn{2}{|c|}{ Insurance } \\
\hline & & CAAR & T-test & CAAR & T-test \\
\hline$(-5,0)$ & \multirow{2}{*}{ 24.11.2016 } & 0,0201 & 1,1690 & 0,0016 & 0,0871 \\
\hline$(0,+5)$ & & $-0,0069$ & $-0,4003$ & $-0,0384$ & $-2,1450$ \\
\hline$(-5,0)$ & \multirow{2}{*}{7.06 .2018} & 0,0158 & 0,7203 & $-0,0051$ & $-0,3461$ \\
\hline$(0,+5)$ & & $-0,0140$ & $-0,6390$ & $-0,0042$ & $-0,2900$ \\
\hline$(-5,0)$ & \multirow{2}{*}{24.09 .2020} & 0,0150 & 0,6081 & 0,0152 & 0,6763 \\
\hline$(0,+5)$ & & $-0,0268$ & $-1,0869$ & $-0,0039$ & $-0,1752$ \\
\hline
\end{tabular}

\section{CONCLUSION}

The policies implemented by the central banks can reach their ultimate goals with the effective functioning of the monetary policy transmission channels. Stock markets are one of the most effective way of these transmission channels. However, stock prices are extremely important in terms of reflecting the changes in both monetary and real sector behavior. Interest rates are very determinant in the transmission of the displayed monetary policy to asset prices. The interest rate, also called the use price of money in a certain period, is a concept determined by market players and represents the cost of capital. Central banks also affect consumption, investment decisions and asset prices by changing the cost of borrowing with the interest policies they apply.prices, examining the effects of policy-based variables is extremely important for understanding the management of the economy.

For this purpose, the effects of the monetary policy decisions of the CBRT on the prices of bank and insurance stocks traded in Istanbul Stock Exchange Market are examined. The event study method was used while examining the effects of monetary policy decisions on the return rates of stocks. Findings are in line with the previous studies which shows that monetary policy decisions have impact on stock prices. Within the evet period which is $[-5,+5]$, according to CAAR and t-test results, it has been determined that the CBRT's decision to increase policy interest rates has a significant and negative effect on the stock prices of banks and insurance firms traded in ISE.

\section{REFERENCES}

Andersson, M. (2007). Using intraday data to gauge financial market responses to Fed and ECB monetary policy decisions. European Central Bank Working Paper Series, 1-36

Bernanke, B. S., \& Kuttner, K. N. (2005). What Explains the Stock Market's Reaction to Federal Reserve Policy? Journal of Finance, $1221-1257$.

Boyd, J. H., Jagannathan, R., \& Hu, J. (2005). The Stock Market Reaction to Unemployment News: Why Bad News is Unusually Good for Stocks. Journal of Finance, 1-41.

Brown, S. J., \& Warner, J. B. (1985). Using Daily Stock Returns: The Case of Event Studies . Journal of Financial Economics, 3-31.

Conover, M. C., Jensen, G. R., \& Johnson, R. R. (1999). Monetary Environments and International Stock Returns. Journal of Banking and Finance, 1357- 1381.

Cook, T., \& Hahn, T. (1989). The Effect of Changes in the Federal Funds Rate Target on Market Interest Rates in the 1970s. Journal of Monetary Economics, 1-31.

D’Amico, S., \& Farka, M. (2002). The Fed and Stock Market: A Proxy and Instrumental Variable Identification. Columbia University, 1-34.

Duran, M., Özlü, P., \& Ünalmış, D. (2010). TCMB Faiz Kararlarının Hisse Senedi Piyasaları Üzerine Etkisi. Central Bank Review, 1-10.

Edelberg, W., \& Marshall, D. (1996). Monetary Policy Shocks and Long-Term Interest Rates. Economic Perspectives-Federal Reserve Bank, 125. 
Fair, R. C. (2006). Events That Shook the Market. The Journal of Business, 1-19. Fama, E. (1970). Efficient Capital Markets: A Review of Theory and Empirical Work. The Journal of Finance, 383-417.

Gökalp, B. T. (2017). Beklenen ve Beklenmeyen Para Politikası Kararlarının Hisse Senetleri Fiyatları Üzerindeki Etkileri. Akdeniz i.i.B.F. Dergisi, 1-15.

He, L. T. (2006). Variations in effects of monetary policy on stock market returns in the past four decades. Review of Financial Economics, 331-349.

Jensen, G. R., Mercer, J. M., \& Johnsonb, R. R. (1996). Business Conditions, Monetary Policy, and Expected Security Returns. Journal of Financial Economics, 213-237.

Rigobon, R., \& Sack, B. (2004). The Impact of Monetary Policy on Asset Prices. Journal of Monetary Economics, 1553-1575.

Thorbecke, W. (1997). On Stock Market Returns and Monetary Policy. Journal of Finance, 635-654.

Vinod, S., Scaria, R., \& S, G. (2020). Monetary Policy Announcement and Stock Price Behaviour: An Event Study with Respect to India. International Journal of Scientific and Thecnology Research, 5724-5731. 